\title{
CRITICAL NOTES ON DIOSPYROS PYRRHOCARPOIDES (EBENACEAE)
}

\author{
M.K. VASUDEVA RAO
}

A-12, Shiv Ranjani Society, Somnath Nagar, Pune 411014, India

\section{SUMMARY}

On critical analysis and taxonomic evaluation, Diospyros pyrrhocarpoides B.R. Ramesh \& De Franceschi is resolved to be only Diospyros ridleyi Bakh., and the former is reduced to a synonym of the latter. The contemporary report of the occurrence of $D$. pyrrhocarpa Miq. and $D$. crumenata Thwaites in the Andaman \& Nicobar Islands is shown to be erroneous.

Key words: Ebenaceae, section Pyrrhocarpoides, Diospyros pyrrhocarpoides, Diospyros ridleyi, Andaman Islands, India.

\section{INTRODUCTION}

Ramesh \& De Franceschi (1993: 133) described a new species, Diospyros pyrrhocarpoides, from the Western Ghats and the Andaman Islands, closely related to the Sumatran species D. pyrrhocarpa. The holotype is from the Bisle Reserve Forest, Hassan District of Karnataka and two of the paratypes are from the Andaman Islands. According to Ramesh \& De Franceschi, the two paratypes, Parkinson 5 and 1666, from the Andaman Islands 'tally exactly' with the Western Ghats specimens. While describing this new species they refer to Kurz's D. pyrrhocarpa var. andamanica Kurz (1877). They state that Kurz 'doubtfully' proposed this variety for the Andaman specimen based on faint and numerous lateral nerves of leaves. They also point out that some earlier collectors erroneously identified the plants of this taxon as D. crumenata.

Recently, Singh (2005) in his monograph on Indian Diospyros, treated D. pyrrhocarpoides as a distinct species and D. pyrrhocarpa var. andamanica conspecific with it. According to this monographic study, D. crumenata, D. pyrrhocarpa and D. ridleyi, also occur in the Andaman Islands. Unfortunately, the specimen Parkinson 666 is both indentified as D. crumenata and as D. pyrrhocarpa. This specimen, as well as Parkinson 1130, reported in this monograph to be D. pyrrhocarpa are studied and reported by Vasudeva Rao (1987) to be undoubtedly $D$. ridleyi and have evidently not been seen by the monographer. Similarly, the specimen Parkinson 42 is identified to be D. pyrrhocarpa as well as D. pyrrhocarpoides [sic!]. Under distribution, it is stated that $D$. ridleyi "finds restricted distribution in the Andaman \& Nicobar Islands of the country" and under phytogeographical aspects, it is stated to have "wide distribution probably due to domestication" in the Islands. 


\section{DISCUSSION AND CONCLUSIONS}

It is evident that Ramesh \& De Franceschi (1993) while describing D. pyrrhocarpoides, had not seen the publication (Vasudeva Rao, 1987) wherein it was unequivocally established that $D$. pyrrhocarpa var. andamanica is $D$. ridleyi. The circumstances that led to the determination, its confirmation, nomenclature, description and the list of specimens studied are well elaborated in this publication. First, critical studies by the present author while identifying the specimens King s.n. (CAL) from the Andamans, marked and kept under Oleaceae, resulted in culling out several other unidentified specimens, both male and female, which were identified as D. ridleyi. And secondly, Ng, then with the Forest Research Institute of Malaysia, while confirming the identification, wrote in a personal communication: "Your determination of the specimen is correct. In fact, I was amazed at the close similarity between your specimen and our FRI 19241 (photo of which was sent to you). They looked as if they could have come from the same tree". So, D. ridleyi, till then known to be endemic to Peninsular Malaysia is now also known to occur in the Andaman Islands (extended distribution) - recorded for the first time through that 1987 publication.

Kurz (1877: 137) proposed his new variety, D. pyrrhocarpa var. andamanica, stating some differences from the typical variety, such as leaf shape, number of lateral nerves and reticulation. He also argued that his new variety from the Andamans might be an altogether different species but did not himself describe it since the "material was too incomplete for description". For Clarke (1882) and later authors, this variety of Kurz remained "exceedingly obscure" and "imperfectly known".

For Bakhuizen van den Brink (1936-1955) the female flowers of this taxon were "probably solitary and subsessile and rest unknown". Ng (1978) also stated that the inflorescence and flowers of the species were unknown. So also for Kurz, when he proposed $D$. pyrrhocarpa var. andamanica. These became known with the description of $D$. ridleyi by Vasudeva Rao (1987).

Parkinson (1923), while treating D. pyrrhocarpa var. andamanica, recorded that some specimens from Middle Andamans differed in having flowers with more globose corolla and leafy 4-folded calyces about 3/4 of an inch in diam. and thought them to belong to the Sri Lankan D. crumenata. On this basis, Singh (2005) also reported that species for the Andaman Islands. These were identified to be D. ridley $i$ with female flowers and the erroneous application of the name D. crumenata was set right (Vasudeva Rao, 1987). There seems to be no record of the occurrence of $D$. pyrrhocarpa (variety proper) for the Andaman Islands other than that of Singh (2005: 210,211). The specimens, studied by him for identifying this tax on for the islands, one from Middle Andamans (Parkinson 42) is also named by Singh himself to be D. pyrrhocarpoides (Singh, 2005: 213, 215). This and other specimens from Betapur valley and Long Island are identified to be nothing else but $D$. ridleyi (Vasudeva Rao, 1987). Thus, D. crumenata and D. pyrrhocarpa are not occurring in these islands as rendered in the monograph.

The description, well-executed illustrations and the cited paratypes from the Andaman Islands that establish the species 'Diospyros pyrrhocarpoides' only lead to the conclusion that it is $D$. ridleyi. The characters, both vegetative and reproductive, of the two 'species' show extreme similarities and the sizes of the parts fall within expectable ranges, except for the female flowers in $D$. pyrrhocarpoides that are stated 
to be sessile and the male flowers to possess 20 stamens by Ramesh \& De Franceschi (1993). These need further confirmation and more material since those specimens of $D$. ridleyi studied by the present author show subsessile or stalked female flowers and male flowers with 12 (or 13) stamens which otherwise match exactly in all respects. The fruit is described to be sessile or subsessile (Vasudeva Rao, 1987). Therefore, $D$. pyrrhocarpoides is reduced here and synonymised with $D$. ridleyi. Hence, the distribution of $D$. ridleyi extends to the Western Ghats of mainland India.

Singh (2005), in order to make the genus "natural, simple and practicable", rendered a subgeneric classification and made a new section, sect. Pyrrhocarpoides, to accommodate the species $D$. pyrrhocarpoides. Since this species is not distinct from $D$. ridleyi the new section is reduced to sect. Campanulata Bakh.

\section{Diospyros ridleyi Bakh.}

Diospyros ridleyi Bakh. (1933) 183; (1938) 354; Ng (1977) 239; (1978) 84, f. 8; Vasudeva Rao (1987) 56, pl. 1; V. Singh (2005) 221, f. 53, pl. 21/2. - Type: H.N. Ridley s.n. (holo SING), Malayan Peninsula, Johore.

Diospyros pyrrhocarpa Miq. var. andamanica Kurz (1877) 137; C.B. Clarke (1882) 572; C.E. Parkinson (1923) 199. - Type from Andaman Islands.

Diospyros pyrrhocarpoides B.R. Ramesh \& De Franceschi (1993) 133, f. 2, syn. nov. - Type: De Franceschi 484 (holo HIFP), India, Karnataka, Hassan, Bisle R.F.

Diospyros pyrrhocarpa auct. non Miq. (1860): Bakh. (1939) 305, pro parte tantum quoad andam. specim.

Diospyros crumenata auct. non Thwaites (1860): C.E. Parkinson (1923) 199, in obs.

Distribution - India: Andaman Islands, Western Ghats, Karnataka, Kerala. Peninsular Malaysia.

Habitat - Near streams or wet places in inland evergreen forests.

Uses - Wood useful as ebony timber.

\section{REFERENCES}

Bakhuizen van den Brink, R.C. 1933. Enumeration of Malayan Ebenaceae. Gard. Bull. Straits Settlem. 7: 161-189.

Bakhuizen van den Brink, R.C. 1936-1955. Revisio Ebenacearum Malayensium. Bull. Jard. Bot. Buitenzorg III, 15: 1-515.

Clarke, C.B. 1882. Ebenaceae. In: J.D. Hooker (ed.), Flora of British India III: 549-572. Reeve \& Co., London.

Kurz, S. 1877. Forest Flora of British Burma II: 137. Superintendent of Govt. Printing, Calcutta.

Miquel, F.A.W. 1860. Diospyros pyrrhocarpa. Fl. Ind. Bat., Suppl.: 583.

Ng, F.S.P. 1977. Notes on the systematy of Malayan Phanerogams. XXVI Ebenaceae. Malaysian Forester 40: 210-248.

Ng, F.S.P. 1978. Ebenaceae. Tree Flora of Malaya III: 56-94. Longman, London, Kuala Lumpur.

Parkinson, C.E. 1923. The Forest Flora of the Andaman Islands. Bishen Singh \& Mahendarapal Singh. Dehra Dun. (Reprinted edition).

Ramesh, B.R. \& D. de Franceschi. 1993. Two new species of Diospyros (Ebenaceae) from India. Blumea 38: 131-136.

Singh, V. 2005. Monograph on Indian Diospyros L. (Persimmon, Ebony) Ebenaceae. Botanical Survey of India, Kolkata, India.

Thwaites, G.H.K. 1860. Enumeratio Plantarum Zeylaniae: 179. London.

Vasudeva Rao, M.K. 1987. A note on Diospyros ridleyi Bakh. (Ebenaceae). Malayan Nat. J. 41: $55-59$. 